\title{
THE INTERNATIONAL UNION FOR THE CONSERVATION OF NATURE AND NATURAL RESOURCES
}

\section{WARSAW AND CRACOW MEETING, JUNE 1960}

Two hundred delegates from thirty-one countries attended the seventh General Assembly of IUCN held in Poland under the presidency of Professor J. G. Baer of Switzerland. Many of them were members of the Fauna Preservation Society, including Lord Hurcomb, Dr. Fairfield Osborn and Dr. V. Van Straelen, vice-presidents, Dr. Peter Crowcroft, Dr. F. F. Darling, Mr. R. S. R. Fitter, members of Council, and the Secretary.

The management of hoofed animals and the effects of poison sprays on wild life were the subjects discussed at the technical sessions. Hoofed animals were tending to increase all over the northern hemisphere, and in many places were becoming too numerous, the red deer in Scotland, for instance. In Russia elk had increased so much that they could be seen wandering in the outer streets of Moscow.

Widespread concern was expressed at the indiscriminate and excessive use of chemical poisons to control animal and plant pests all over the world. In some cases, as with the campaign against the fire-ant in the United States, it was not even certain that the creature in question was a pest, yet millions of other creatures were killed at the same time. In other cases resistant strains of the pests (up to 90 per cent with some mosquitoes) were being built up so rapidly that chemical control would soon become impossible.

Several speakers stressed the need to make more use of biological methods of controlling pests. In Italy transplanted colonies of predatory ants had successfully controlled pine defoliators in woodland. In the United States shrews had been used to control insect pests in forests, and in Canada a combination of chemical and biological methods had been successfully used to control orchard pests.

Mr. E. M. Nicholson announced that the British Nature Conservancy was just setting up a small unit to research into the effect of the use of poison sprays on wild life. It would include an entomologist, a vertebrate zoologist, and a botanist ; a chemist, who would interpret the problems of the biologists to the manufacturers, would also join the unit.

At the close of the Assembly the resignation of Mr. M. C. 
Bloemers as Secretary-General was announced, also the proposed move of the Union to Switzerland. Mr. Bloemers' resignation was accepted with great regret, and he agreed to remain in office as long as the headquarters of the Union remained in Brussels.

During and after the conference visits were paid to national parks on the borders of Czechoslovakia, Russia and the Baltic Sea. An article about the parks and nature conservation in Poland generally will appear in the next Oryx.

\section{African Special Project, 1960-63}

African problems were prominent in the Assembly and the Union decided to launch in co-operation with UNESCO, FAO (the International Food and Agriculture Organization), and CCTA (Committee for Technical Co-operation in Africa south of the Sahara), and with the governments of countries in tropical Africa a special project the purpose of which will be to inform and influence public opinion, through its leaders and responsible persons in governments, towards the realization that the application of conservation, based on ecological knowledge, is in the best interests of all African countries. Conservation in this sense applies to water, soils, vegetation, and wild life, although special attention will be given to the large mammals, which provide an important natural resource, but which are seriously endangered in many areas. This project will be focused primarily on the wild habitats, including national parks, faunal reserves, nature reserves, and also other wild lands which, under management, are capable of producing crops of animal protein and other wild products on a sustained yield basis.

The project is being organized as follows :

\section{Stage I : 1960 to early 1961}

A small group of African persons will be organized under the leadership of Mr. G. G. Watterson, of the FAO African Regional Office, to discuss the principles and practices of conservation with the leaders of African opinion. One or two of the Africans may travel through parts of Africa with Mr. Watterson; others may be appointed as agents in particular countries or areas.

The cost of Stage $I$ is expected to be between $\$ 3,000$ and $\$ 4,000$ and this has been guaranteed equally between the Fauna Preservation Society and the Zoological Society of New York. The project has therefore now been launched on its first stage, which will pave the way for : 
Stage II : Proposed for September, 1961

A Conference on the Conservation of Nature and Natural Resources in modern African States to be arranged in Africa. This conference will be in two parts :

Part I.-Technical discussions-limited in scope to nature and natural resources in the wild lands of Tropical Africa. This will take approximately three days and be attended by specialist workers mainly from Africa.

Part II.-Administrative and political implications. For this section the scope will be widened to the application of conservation principles to land which has been brought into production, e.g. for forestry and agriculture, as well as to lands where nature is still dominant. In addition to the members attending Part I, it will include leading African personages nominated by the African Governments or specially invited to attend. It will last three or four days, of which two days will be devoted to a field excursion.

Stage III.-1961-62-A whole-time staff unit will be appointed consisting of an experienced ecologist and an education specialist with one or two secretaries. This unit will be attached to the headquarters of IUCN, and will work in Africa for part of each year. The special purpose will be to put into operation recommendations which emerge from Stage II of the project. The work of this unit will be closely integrated with the programmes in Africa of FAO, UNESCO and CCTA.

Stage III is estimated to cost about $\$ 29,000$ in its first yearsalaries, travelling, documentation and administration.

Money has not yet been arranged for Stages II and III of this urgent programme.

An African Advisory Committee has been formed to implement this programme: Chairman-Dr. E. B. Worthington; Secretary-G. Treichel, Staff Ecologist, IUCN.

\section{The Survival Service Commission*}

Many ordinary meetings of the Commission were held and one special meeting open to all members of the Assembly. At a General Meeting of the Assembly, the Chairman briefly described the work of the Commission.

The Commission's exhibition was on view throughout the conference and was favourably regarded.

It consisted of three charts of the world showing :

* An article on the origin, purpose and construction of the Survival Service Commission will be found in Oryx, V, 1, April, 1959. 
(a) locations of animals already on the endangered list;

(b) other animals in danger of extermination ;

(c) sea mammals exterminated or threatened with extermination ;

(d) a large map of Africa giving the results of the Black Rhinoceros survey.

Copies of the Lee Talbot report, "A Look at Threatened Species" were sold, and the original drawings by G. Christman illustrating it were exhibited.

\section{Endangered Species}

The Commission agreed that it was hardly possible, even if desirable, to keep one list of all endangered species, and decided to divide the list into three schedules as follows:

Definition: the word "forms" will be used to denote "species" or "subspecies".

Schedule 1 (a) Forms demanding urgent attention for which practical steps seem possible and for which publicity would be advisable and useful.

(b) Other endangered forms which demand urgent attention but to which the other conditions of Schedule 1 (a) do not apply.

Schedule 2 Endangered forms whose status should be watched and for which action should be taken whenever practicable.

Schedule $3 \quad$ Very rare forms for which measures have already been taken which may reasonably be expected to avert their extinction.

Unfortunately the names of very many animals will appear in these schedules and work on them is continuing. Schedule $1(a)$ will be published.

\section{Resolution}

The following resolution presented by the Survival Service Commission was passed by the General Assembly on 24th June, 1960 :

The VIIth General Assembly of the International Union for the Conservation of Nature and Natural Resources-

believing that a major threat to the existence of some rare animals is their illegal exportation from the country of origin, followed by their legal importation into other countries; warmly approves the action of those countries which have restricted the importation of such animals ; 
now resolves that the International Union for the Conservation of Nature and Natural Resources should urge all governments which do not yet restrict the importation of rare animals in harmony with the export laws of the countries of origin, to do so now and thereby support the efforts of other countries to preserve animals in danger of extermination.

\section{Black Rhinoceros Survey, 1959-1960}

The Survival Service's inquiry into the status of the black rhinoceros was prompted by the concern of Mr. M. Cowie at the alarming rate at which its numbers were diminishing. In Kenya the number killed annually represents 20 per cent of the total population, whereas the normal annual increase is only 5 to 8 per cent. Here, as elsewhere, the reason for poaching is the ready sale of horn, the price of which has reached $100 \mathrm{~s}$. a pound.

Letters directed to responsible persons in each country where the black rhinoceros still exists gave the following figures : The Cameroons, 200-300 ; French Equatorial Africa, 500-1,000 ; Sudan, 200-300 ; Ethiopia, 100 ; Somalia, 15-50 ; Kenya, 2,560 ; Uganda, 525; Tanganyika, 3,000-4,000 ; Congo, 6 ; Northern Rhodesia, 1,000 ; Southern Rhodesia, 1,500 ; Mozambique, 500 ; Angola, 150-200 ; South-West Africa, 280 ; Bechuanaland, 20; Union of South Africa, 312. This makes a total of between 10,800 and 12,500 rhinoceroses with the largest concentration in East Africa.

Though in many of these countries (Sudan, Ethiopia, Tanganyika, Northern Rhodesia, Mozambique and the Union of South Africa) the black rhinoceros enjoys complete legal protection, only in the Union of South Africa was this legislation considered to be completely effective against poaching. In some countries, Somalia, Kenya and Angola for instance, this rhinoceros is fully protected within the boundaries of national parks and reserves but elsewhere may be hunted on licence. In Uganda a special licence is required, and these have been suspended during the last seven years. Southern Rhodesia classes rhinoceroses as Royal Game, South-West Africa and Bechuanaland as Protected Game.

The black rhinoceros was found to have disappeared completely from British Somaliland, where the last one was shot over thirty years ago. In Somalia its prospects of survival are very doubtful. In Sudan the outlook is brighter, for it lives in thinly-populated or uninhabited areas. Angola expects numbers to increase in the national park of Porto Alexandre which is 
carefully patrolled, whilst in Mozambique, the Nature Preservation Society is asking the government to establish two new reserves to give further protection to the species.

Outside of reserves the black rhinoceros has little chance of survival ; its future may depend on how soon money can be made available to immobilize, capture and move rhino to "safe areas".

\section{Birds}

The following report on the status of certain birds was received from The International Council for Bird Preservation. These birds had been put on a list of examples of vanishing species drawn up at the UNESCO International Technical Conference on the Protection of Nature, held at Lake Success in 1949.

1. Arabian ostrich (Struthio camelus syriacus). This bird has not been seen since 1941 and is perhaps extinct. However, no determined search has been made to verify its status.

2. Hawaiian goose (Nesochen sandvicensis). The captive breeding programme of this species has been highly successful and there is little doubt that the species can be continued in captivity. The wild bird population in Hawaii is estimated at 35, which is considerably exceeded by the captive population of about 135 . It is still planned to re-establish this bird in suitable areas of its original habitat.

3. New Caledonian kagou (Rhinochetus jubatus). No change in status.

4. Indian pink-headed duck (Rhodonessa caryophyllacea). The rarity of this species has been well published in India. No sighting has been reported since 1935 at the latest.

5. Australian ground parakeet (Pezoporus zoallicus). A new law dated 1st January, 1960, now prohibits exportation of specimens except for scientific purposes-a step in the right direction. No known change since 1958.

6. Laysan duck (Anas laysanensis). Well protected and apparently as numerous as possible in such a restricted habitat. In 1958 there were over 500 birds on Laysan Island, as well as 30 in captivity. In 1959 nine young were reared in captivity.

7. Marianas mallard (Anas oustaleti). It has been suggested that this bird may be an unstable hybrid $(A$. platyrhynchos $\times A$. superciliosa) and perhaps should be removed from the list. This matter will receive the attention of the International Council for Bird Preservation.

8. Cuban ivory-billed woodpecker (Campephilus principalis bairdii). No recent information has been received regarding the status of this bird. Its restricted mountain habitat is in an area which was the main headquarters of the revolutionary army in Cuba and it is possible that the population was further reduced.

9. Bermuda petrel (Pterodroma cahow). 'This population, even though small and restricted, is in no immediate danger. The known two to three breeding pairs are well protected.

10. Marianas megapode (Megapodius laperouse). No known change in status. 
11. California condor (Gymnogyps californianus). It is estimated, February, 1960 , that some 60 to 65 individuals exist. Ten individuals were seen feeding during the first week in January, 1960. They appear to be as well protected as is possible.

12. Eskimo curlew (Numenius borealis). 'This bird was possibly sighted on Galveston Island, Texas, in the spring of 1959 by members of the Texas Ornithological Society. A single bird which was identified as an Eskimo curlew was seen on five separate occasions during March and April in company with whimbrels and golden plovers. One observation was made from 60 feet. This is the first reported probable sighting since 29th April, 1945, and in the same location.

13. North American whooping crane (Grus americana). In the fall of 1959, thirty-three birds reached Texas from Canada. There were, however, only two young birds as compared to nine in the previous year. There are two adults and three juveniles in the New Orleans Zoo and one adult in the San Antonio Zoo. None were bred in captivity in 1959 . There are now thirty-nine birds, the highest recorded since 1938 .

14. Steller's albatross (Diomedea albatrus). A report from the Torishima Meteorological Station on the 1958-59 breeding 'season stated that the small nucleus of birds has prospered steadily and that during the season eighteen chicks were hatched. Including these chicks, there are now more than fifty birds on the island.

\section{Present Work of the Commission}

While the Conference was still in progress, Mr. E. P. Gee was at work in Manipur inquiring into the status of the Manipur Browantlered deer which inhabits only the Logtak lake, and making suggestions for its preservation. His recommendations will be published in the next Oryx.

\section{INFORMATION WANTED}

Leathery turtle (Dermochelys coriacea)

Manatee (Trichechus Sp.)

Dugong (Dugong dugon)

The Survival Service Commission of the International Union for the Conservation of Nature is inquiring into the status of the above animals, which may soon be in danger of extermination. Please send information under the following headings to The Fauna Preservation Society.

1. Animal dealt with.

2. Area dealt with.

3. Present breeding areas.

4. Old breeding area no longer used.

5. Past and present status, including numbers.

6. Occurrence at sea.

7. Legal protection. 
8. Other conservation measures.

9. Prospects of survival.

10. Other information and suggestions.

\section{Australia}

The Commission received the following report on the endangered mammals of Australia. Besides its great general interest the report illustrates the difficulty of making a world list of endangered species. 